Northwestern University School of Law Northwestern University School of Law Scholarly Commons

Faculty Working Papers

1990

\title{
The Invasion of Panama Was A Lawful Response to Tyranny
}

Anthony D'Amato

Northwestern University School of Law, a-damato@law.northwestern.edu

\section{Repository Citation}

D'Amato, Anthony, "The Invasion of Panama Was A Lawful Response to Tyranny" (1990). Faculty Working Papers. Paper 137. http://scholarlycommons.law.northwestern.edu/facultyworkingpapers/137 


\title{
The Invasion of Panama Was A Lawful Response to Tyranny, by Anthony D'Amato*, 84 American Journal of International Law 516-524 (1990)
}

\begin{abstract}
The Grenada and Panama interventions contributed to the momentum of popular sovereignty. Not only did the United States remove tyrannical leaders from those two countries, but more importantly it set an example that has undoubtedly shaken other ruling elites that enjoy tyrannical control in their own countries. For even if some of those entrenched elites regard themselves as secure against popular uprising in their own countries (usually by the application of torture and brutality against political dissidents), they cannot now feel totally insulated against foreign humanitarian intervention. Thus, Grenada and Panama may very well act as catalysts in the current global revolution of popular sovereignty. In this respect, as well as on their own merits, the two interventions underscore the unraveling of statist conceptions of international law. The arguments of Professors Farer and Nanda, struggling to conform to the tautological jargon of statism, already seem anachronistic.
\end{abstract}

Tags: Transboundary Use of Force, Article 18 of the OAS Charter, Article 2(4) of the UN Charter, U.S. Intervention in Panama 1989-1990

I.

[pg516]** What Professors Tom Farer and Ved Nanda do not seem to understand is the positive implication for the development of human rights resulting from the United States intervention in Panama. [FN1] Their views are so conditioned by a statist conception of international law that they seem unable to see through the abstraction that we call the "state" [FN2] to the reality of human beings struggling to achieve basic freedoms. I am not talking about the human rights of American "matrons domiciled in Panama," as Professor Farer puts it, who were "rescued" in 19th-century expeditionary-force style. [FN3] Rather, I am talking about the human rights of Panamanian citizens to be free from oppression by a gang of ruling thugs. My focus is on the basic civil liberties and fundamental freedoms of the people of Panama themselves.

Although I am confident that Professors Farer and Nanda are personally committed to the cause of human rights, it seems that when they put on their formalistic hats and talk about international law, they revert to the Oppenheimian notion that international law is all about states and not at all about people.

For example, Professor Farer says that "[i]f sovereignty means anything, it means that one state cannot compromise another state's territorial integrity or dictate the character or the occupants of its governing institutions." [FN4] But why should "sovereignty" mean anything? Who assigns it its meaning? Why should its meaning have legal consequences? How is even its Farerian meaning compatible with the enforcement against states of the evolving rules of international law? Professor Farer-according to his own "Humpty-Dumpty school of linguistic usage" [FN5] - may proclaim that his words mean only what he wants them to mean, but is he entitled to exercise definitional sovereignty over others?

Professor Nanda joins Professor Farer in relying upon Article 18 of the OAS Charter to say that international law denies to any state the right to intervene directly or indirectly in the internal or external affairs of any other state. I do not doubt that the representatives of states at the OAS in 1948 wanted such a principle-they adopted it without much debate. But I will 
[pg517] argue that the wishes of those representatives and their academic apologists are far less important to international law than the actual customary-law-generating behavior of states. The U.S. interventions in Panama and, previously, in Grenada are milestones along the path to a new nonstatist conception of international law that changes previous nonintervention formulas such as Article 18.

Like Professor Farer, I want to illustrate my argument by an analogy. In the 19th century, United States courts refused to intervene when wives applied for judicial help against beatings inflicted by their husbands. Some judges repeated the saying, "A man's home is his castle." Most judges observed that the wife has an adequate remedy if her husband hits her-she can sue for a divorce. And nearly all judges opined that intrusion by the "heavy hand of the state" would provide a cure that was worse than the disease. Simple prudence, according to the judges, required a judicial policy of abstention from domestic problems. And what was considered prudent rapidly became transformed into a "neutral principle"-that the law will not intervene in the home on behalf of either spouse.

Courts now recognize that battered wives need and deserve judicial protection. Historians look back at the 19th century and speculate about how much brutality, how much horror, women had to endure at the hands of physically stronger spouses who treated them like chattel. Law students recognize that 19th-century judicial abstention from battery in the home was not the "neutral principle" it was advertised to be; rather, its apparent evenhandedness served to insulate the physically stronger marriage partner against any external compensatory force that could be provided by the police. And legal philosophers now realize that words found so abundantly in the old opinions such as "home" and "domestic" and "marriage" do not stake out lines of jurisdiction but, rather, beg the question of where and for what purposes there ought to be jurisdiction.

The citizens of Panama were as powerless against Noriega and his henchmen as the 19th-century American wives were against physically stronger husbands. In describing Noriega's rule, we should discard loaded words like "government," "legitimate," "authority," "army," "police," and so forth. These words only serve to dull our senses against the reality of power by begging the very question that is the subject of the present debate-whether Panama's borders should be treated as an exclusive reservation of "domestic jurisdiction" to Noriega or whether those borders should be permeable for some purposes.

Noriega ruled Panama because he and his co-thugs controlled the guns, rockets, mortar, truncheons and tear gas. Any citizen who defied Noriega by rational argument risked being answered by bullets. Jails were used to hold political prisoners-citizens who disagreed too loudly with Noriega. Somehow, miraculously, there was an election in May 1989, and Noriega's candidate was defeated. No matter; Noriega had the power. The opposition candidates appealed to reason, to fairness, to the will of the people; Noriega invoked the logic of brute force, of steel, of gunpowder, of the infliction of imprisonment and disappearance. The electoral victors were crushed.

[pg518] Did Noriega have any "right" to rape Panama for his own ends, to exult in unrestrained power, to ignore or trample on the rights and needs of the people who were his 
"subjects"? If he had any "right" under Panamanian law, it was because he made that law. (The 19th-century husband also "made the rules" of the household and was himself "above the law"if his wife did not like it, he could "make her like it" by the application of force.) What about a "right" under international law? Professors Farer and Nanda wish to interpret international law in such a way that it hands Noriega such a right on a silver platter.

Professor Farer makes his argument with commendable half-heartedness. He puts quotation marks around the word "legitimate" when he says that "Noriega and his associates were, for purposes of international law, the 'legitimate' Government of Panama." [FN6] But it is a crabbed 19th-century interpretation of international law that Professor Farer here invokes, and he signals his reluctance to invoke it by the quotation marks. He concedes that his legitimacy argument "can sometimes seem repulsive from a moral perspective." [FN7] We may well wonder why so sensitive an observer of international relations as Professor Farer [FN8] feels compelled to brush morality aside. He writes:

But by allowing legitimacy to turn on a single fact that is relatively easy to verify, the practice serves the important policy of inhibiting intervention. Thus, it protects the central Charter value of national autonomy. [FN9]

In other words, Professor Farer has been carried away by the rhetoric of statism. He urges us to treat states tenderly even at the morally repulsive cost of refusing to help the citizenry get out from under tyrannical rule. According to Farer, because we can easily tell that Noriega was in charge of Panama (just look at his guns, his brutality, the fact that he ran local television), this easy identification "serves the important policy of inhibiting intervention." But what connection is there between readily identifying the head of state and inhibiting intervention? Would Professor Farer accept intervention in a country where the people govern themselves through town meetings, because in such a country the fact of who's in charge is not easy to verify? Since when, and by whom, was ease of identification elevated to one of the most important values in the international system? And does not his entire argument of ease of identification presuppose the question whether intervention should be inhibited? What about his last sentence-"the central Charter value of national autonomy"? Who proclaimed this to be the central value of the UN Charter? Whatever happened to human rights? A glance at the Preamble to the UN Charter reveals its affirmation of "faith in fundamental human rights," "social progress," and "economic and social advancement of all peoples"; there is no mention of national autonomy.

[pg519] Professor Nanda refers more directly than does Professor Farer to the problem of Noriega's "autocratic rule," "strong-arm tactics," and nullification of the election of May 1989. [FN10] Nevertheless, Professor Nanda can find "no legal basis for replacing that rule with democracy." [FN11] Here, at least, I agree with the rhetoric of Professor Nanda's statement: surely there is no Wilsonian principle of international law that permits intervention to impose a democratic form of government in another state, any more than there is a Brezhnev Doctrine in international law that permits intervention to impose or restore a socialist or Communist form of government. But concepts such as "democracy" and "socialism" are profoundly beside the point. Again, consider the 19th-century battered wife. She was not appealing to the courts to impose a particular form of government in her household; rather, she sought protection from brutality and enslavement. Analogously, at the governmental level, the question we should ask is not what 
intervention is for but what it is against. I argue that human rights law demands intervention against tyranny. [FN12] I do not argue that intervention is justified to establish democracy, aristocracy, socialism, communism or any other form of government. But if any of these forms of government become in the Aristotelian sense corrupted, [FN13] resulting in tyranny against their populations - and I regard "tyranny" as occurring when those who have monopolistic control of the weapons and instruments of suppression in a country turn those weapons and instruments against their own people [FN14] - I believe that intervention from outside is not only legally justified but morally required.

II.

There are several interim questions that can be raised about the argument I have sketched so far. Among the more conspicuous are the following.

1. What country may intervene? My preference would clearly be in favor of multilateral intervention, such as that of France, Great Britain, and Russia in the Greco-Turkish conflict of 1827, one of the earliest cases of humanitarian intervention. [FN15] Today, the best "intervener" would be the United Nations. But the Security Council's armed forces have never been called into being, and the General Assembly has mounted only defensive peacekeeping forces —and then only on rare occasions. Regional arrangements would be preferable to unilateral action. But my bottom line is that I maintain that any nation with the will and the resources may intervene to protect the population of another nation against the kind of tyranny that was about to gain a foothold in Grenada in 1983 (when a group of thugs machine-gunned their way into [pg520] power, murdering the existing democratic rulers), and against the kind of tyranny exhibited by Noriega in Panama. Although I would have preferred other Latin American nations to have joined in the intervention in both these cases, since they chose not to do so, it was left to the United States to safeguard unilaterally the fundamental freedoms of the people of Grenada and of Panama.

2. Did the United States have a right to invade Panama to arrest Noriega because he was under indictment in Florida for dealing in drugs? Professors Farer and Nanda have rehearsed the reasons given by President Bush for the Panamanian action, but they do not necessarily constitute justification under international law. The only reason he gave that even comes close to the justificatory reason I have suggested in this paper is "to help restore democracy." No matter; a state is not required under international law to cite valid international law reasons for its actions. [FN16] International lawyers may appropriately evaluate the actions states undertake on the basis of customary international law irrespective of verbal rationales proffered by the states themselves. [FN17]

3. Did the United States violate Article 2(4) of the Charter? There is no doubt that under our present understanding of international law the use of military force for the purpose of territorial aggrandizement or colonialism violates customary international law. Nor is there any doubt that such use of force would not count as humanitarian intervention even if appropriately disguised at the time-rather, it would be regarded as pure aggression. I submit that the core intent of Article 2(4) was to secure these understandings. [FN18] Accordingly, the U.S. forcible intervention in Panama did not violate Article 2(4) because the United States did not act against the "territorial 
integrity" of Panama: there was never an intent to annex part or all of Panamanian territory, and hence the intervention left the territorial integrity of Panama intact. Nor was the use of force directed against the "political independence" of Panama: the United States did not intend to, and has not, colonialized, annexed or incorporated Panama. Before and after the intervention, Panama was and remains an independent nation.

4. Who determines whether a target nation is under tyrannical rule? This question is a variant on the formalist objection to any transboundary use of force: the asserted relativity of justification. Scholars such as Professor Oscar Schachter prefer "neutral" rules that totally outlaw transboundary force, [pg521] despairing of the imagined subjectivity that would be involved in any attempt to determine whether a given use of force was justified. [FN19] Such a position seems good in theory, but inevitably deconstructs itself. For example, Professor Schachter must admit a loophole for the use of force in self-defense, [FN20] but it is a loophole that gets wider the more one looks at it. Any state can claim that it has acted in self-defense, and in many cases the mere claim will seem credible. If in some cases it appears strained, the aggressor can cover by using phrase "anticipatory self-defense." The fact is that we cannot delineate "self-defense" in advance to cover future contingencies of often-increasing complexity. Generally speaking, neutral-sounding formulas are not and cannot be self-interpreting; rather, in any case of real-world aggression, there will be disputes as to the meaning and applicability of such formulas. The end result is that all the facts and circumstances surrounding the alleged aggression will have to be taken into account in assessing whether or not it was an illegal aggression. Hence, Professor Schachter's position does not and cannot do the job it sets out to do- - to prevent subjective interpretation of rules of law-but, rather, will only serve to divert scholars from the real values at stake and instead lead them into academic, abstract and formalistic linguistic exercises.

Since the job of looking at the facts and circumstances has to be done by the international lawyer anyway, I claim that my position is certainly no more problematic than Professor Schachter's. I assert that we must inquire into the factual situation whether Noriega was a tyrannical ruler. The term "tyrannical" is almost as vague as the term "aggression," [FN21] but not quite - though people may differ on the range of behavior that constitutes tyranny, there is probably consensus both outside and inside Panama that Noriega fits the bill. Certainly neither Professor Farer nor Professor Nanda disputes Noriega's entitlement to the status of "tyrant."

Another way of stating my point is that there is no "objective" language in international law. All rules of law must be interpreted; all interpretation varies with context; all interpretation is necessarily subjective. We are better off with rules of international law that at least point us to important factual and contextual considerations than we are with rules that point us only to an endless series of subrules, explanatory rules and learned commentary regarding the interpretation of all of those rules - commentary that then itself must be interpreted. The important factual and contextual considerations in the present case, I submit, are whether the people of Panama were helpless under a tyrannical rule and deserved, in morality and in law, aid from an [pg522] outside power to remove the unlawful government that was brutalizing them. The factual situation of the people of Panama cannot be found by consulting textbooks on the legality and exceptions regarding the use of force in international relations. 
5. How can the death of over seven hundred innocent Panamanian citizens be justified? I believe that the United States used too few troops (some 24,000) in the military attack on Panama, with the result that these troops overcompensated for their small numbers by the disproportionate use of force. [FN22] If at least ten times that number had been deployed, such an overwhelming presence of military forces would have reduced their felt need for firing their weapons. Moreover, in the presence of such superior numbers, Noriega's defenders may have surrendered much sooner. It is extremely ironic that the legal uneasiness felt by the United States in undertaking the Panamanian operation-reflected in the kinds of arguments Professors Farer and Nanda have put forth, arguments that were surely repeated in top decisional circles probably led to the deployment of as few troops as possible. There was undoubtedly a fear that a massive use of troops would appear somehow to be a greater violation of international law. If, instead, the position that I am urging had been the consensus position among American international lawyers and advisers to President Bush, more troops may well have been deployed with a consequent reduction in civilian casualties. Thus, the very fear that the Panamanian intervention was illegal became, in the event, ironically self-confirmatory with respect to the unfortunately high number of civilian casualties.

III.

No matter how I interpret Article 2(4) of the UN Charter, Professors Nanda and Farer would say that a different provision of a different multilateral treaty-Article 18 of the OAS Chartershuts the door tightly against any form of transboundary military intervention. I will not undertake a textual analysis of Article 18, replete though it is with vast ambiguities (as Professor Farer concedes). Rather, let us assume that the text could be cited for the proposition that Professors Nanda and Farer want.

I could make, although at the present time it would be unpersuasive to make, the following argument.

Article 18 is the self-interested expression of ruling elites of Latin American countries establishing a nonintervention cartel so that they will each have free rein (reign) in their own nations. Whenever diplomats get together and sign a multilateral treaty, the easiest thing they can agree upon is noninterference in each other's internal affairs. If we want to take human rights seriously, we cannot give much weight to conspiracies among ruling elites that do not represent the views of their populations. If the international law of human rights springs from the people, and not the elites that run governments, then so much the worse for the nonintervention treaties invented by the latter for their own self-interest. They do not constitute real rules of [pg523] international law but, rather, are quasi-rules, invented by ruling elites to insulate their domestic control against external challenge. [FN23]

The foregoing is, I repeat, an argument that is unpersuasive now, although someday in the future-if the human rights revolution in international law continues its present course - the same argument may seem intuitively obvious. At the present time, treaties generate rules of customary law, and one of the customary rules of treaty formation continues to be that the credentials of representatives of governments of the signatory states are taken at face value. 
But if treaties generate customary rules when they come into force, treaties do not "freeze" such customary rules forever. Rather, new rules of custom may arise out of the practice of states, and these new rules of custom may alter the previous treaty-generated rules. [FN24] Although this argument is obvious, scholars are often misled by the unvarying text of treaties. The words of Article 18, although the OAS Charter was signed in 1948, still look the same in 1990. Professors Farer and Nanda cite those words as if they were timeless. But, in fact, customary practice since 1948 has superseded whatever legal impact those words had on international law in 1948.

A major customary law development since 1948 was the intervention by the United States in Grenada in 1983, and a second one is the Panamanian intervention of 1989. I argued at the time of the Grenada intervention that it was a lawful and temporary humanitarian intervention to free the people of Grenada from the tyranny of the thugs who had machine-gunned their way into power. [FN25] Fortunately for my argument, the U.S. military forces pulled out of Grenada soon after their mission was accomplished, and now the episode can safely be cited as an instance of limited humanitarian intervention on behalf of the citizens of Grenada. Assuming that the U.S. forces continue to pull out of Panama (as they are doing at this writing), the Panamanian intervention will be a reaffirming instance of this new customary rule that changes the previous rule flowing out of Article 18. [FN26]

\section{[pg524] IV.}

The real world is changing faster than the paradigms of scholars. The Berlin Wall has crumbled with a suddenness that surprised everyone, but in fact it was merely a visual manifestation of the dynamic logic of popular sovereignty that is sweeping through Eastern Europe. Tyrannical leaders are being replaced in nation after nation by governing bodies that are more responsive to the citizenry.

Contributing to the momentum of popular sovereignty are the Grenada and Panama interventions. Not only did the United States remove tyrannical leaders from those two countries, but more importantly it set an example that has undoubtedly shaken other ruling elites that enjoy tyrannical control in their own countries. For even if some of those entrenched elites regard themselves as secure against popular uprising in their own countries (usually by the application of torture and brutality against political dissidents), they cannot now feel totally insulated against foreign humanitarian intervention. Thus, Grenada and Panama may very well act as catalysts in the current global revolution of popular sovereignty. In this respect, as well as on their own merits, the two interventions underscore the unraveling of statist conceptions of international law. The arguments of Professors Farer and Nanda, struggling to conform to the tautological jargon of statism, already seem anachronistic.

\section{Footnotes}

\section{* Of the Board of Editors.}

**Numbers in the format "pg516" etc. refer to the pagination of the original publication. 
[FN1]. See Farer, Panama: Beyond the Charter Paradigm, supra p. 503; Nanda, The Validity of United States Intervention in Panama under International Law, supra p. 494.

[FN2]. For an important discussion of the concept of "state" from the viewpoint of transboundary intervention, see F. TESÓN, HUMANITARIAN INTERVENTION: AN INQUIRY INTO LAW AND Morality (1987). I do not subscribe entirely to Professor Tesón's views about Hegel; I think that the "state" is more than the sum of the individuals living in it at any given time, and hence is properly accorded some degree of autonomous consideration. See D'Amato, The Relation of the Individual to the State in the Era of Human Rights, 24 TEX. INT'L L.J. 1, 7-11 (1989).

[FN3]. P. 504 supra.

[FN4]. P. 507 supra.

[FN5]. P. 514 supra.

[FN6]. P. 510 supra.

[FN7]. P. 511 supra.

[FN8]. See his excellent study, T. FARER, THE GRAND STRATEgy of the United STATES IN LATIN AMERICA 69-78 (1988) (dealing with the Inter-American Commission on Human Rights).

[FN9]. P. 511 supra.

[FN10]. P. 498 supra.

[FN11]. Id.

[FN12]. See Reisman, Coercion and Self-Determination: Construing Charter Article 2(4), 78 AJIL 642 (1984).

[FN13]. ARISTOTLE, Politica, bk. III, chs. 6-13.

[FN14]. A good elaboration of this definition is found in J.S. FISHKIN, TYRANNY AND LEGITIMACY: A CRITIQUe Of Political Theories 12-25 (1979).

[FN15]. The intervention, claimed to be under the auspices of the Treaty of Locarno, was aimed at protecting Christians who were being persecuted by Turkey. See $1 \mathrm{~L}$. OPPENHEIM, INTERNATIONAL LAW 312-13 (H. Lauterpacht 8th ed. 1955).

[FN16]. Nor is there any requirement that the intervention be actuated by a legally proper motive. In the case of governments, it is impossible to tell what motivated the action, and if the government explains its motivation, it is still impossible to tell whether the explanation is accurate. I have attempted to spell this out more fully in A. D'AMATO, THE CONCEPT OF CUSTOM IN INTERNATIONAL LAW 34-39 (1971). 
[FN17]. Pace the curious argument of Michael Akehurst that what states say is more important than what they do. Akehurst, Custom as a Source of International Law, 47 BRIT. Y.B. INT'L L. 1 (1974-75). He seems to have forgotten that what Professor Henry Higgins observed of the French in My Fair Lady was meant to be ironic: "The French don't actually care what you do, as long as you pronounce it properly!"

[FN18]. I have attempted to state this position in some historical and legal detail in A. D'AMATO, INTERNATIONAL LAW: PROCESS AND PROSPECT 57-73 (1987).

[FN19]. See Schachter, International Law in Theory and Practice, 178 RECUEIL DES COURS 13, 58-60 ("The Quest for Objectivity"), 133-87 (use of force and exceptions) (1982 V).

[FN20]. Id. at 150-66.

[FN21]. The term "aggression" is notoriously vague and ambiguous. Consider the dispute as to which side was the aggressor in the recent Iran-Iraq War or in the Vietnam War (North Vietnam or the United States?). Consider also the various types of aggression that have been seriously suggested in the United Nations such as cultural aggression and economic aggression. If nation A commits cultural aggression against nation B, may B counter militarily against A and call it self-defense?

[FN22]. Additionally, as in the case of the military intervention in Grenada, U.S. troops apparently were ill-trained for "surgical" missions where many innocent civilians are present.

[FN23]. For the argument that human rights law trumps even an explicit intergovernmental waiver of liability, see D'Amato \& Engel, State Responsibility for the Exportation of Nuclear Power Technology, 74 VA. L. REV. 1011 (1988).

[FN24]. See, with respect to Article 2(4) of the UN Charter, Franck, Who Killed Article 2(4)?, 64 AJIL 809 (1970); cf. Henkin, The Reports of the Death of Article 2(4) Are Greatly Exaggerated, 65 AJIL 544 (1971).

[FN25]. D'Amato, Intervention in Grenada: Right or Wrong?, N.Y. Times, Oct. 30, 1983, at E18, col. 3.

[FN26]. Assuming that Article 18 of the OAS Charter generated a customary rule of nonintervention when it came into force, and assuming that I have proven that subsequent customary law development has changed the rule into one of intervention to prevent tyranny, what about the inter se obligations of the parties to the OAS Charter? Those obligations, I suggest, could remain the same. It is possible to violate a treaty obligation even though the same action is now legal under customary law. But we would not say that such action is illegal under "international law"; rather, it is only "illegal," if at all, under the particular treaty regime and only with respect to the particular sanctions, if any, provided by the treaty itself. To be sure, the parties to the treaty may wish to interpret the subsequent customary law development as constituting a "changed circumstance" so that their interpretation of the treaty is not at variance 
with the newly formed custom. For a discussion of the analogous case of Article 2(4) of the UN Charter, see D'Amato, Trashing Customary International Law, 81 AJIL 101 (1987). 